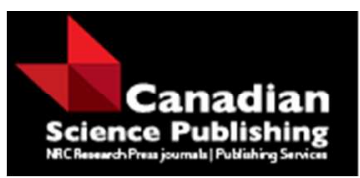

Canadian Journal of Forest Research

Revue canadienne de recherche forestière

\title{
A Categorical Modeling Approach to Analyzing the Impacts of the Lacey Act 2008 Amendment on Chinese Companies' Export Cost and the Implications on Their Sourcing Behaviors
}

\begin{tabular}{|r|l|}
\hline Journal: & Canadian Journal of Forest Research \\
\hline Manuscript ID & cjfr-2015-0163.R1 \\
\hline Manuscript Type: & Article \\
\hline Date Submitted by the Author: & 06-Aug-2015 \\
\hline Complete List of Authors: & $\begin{array}{l}\text { Lu, Ziyi; University of Washington } \\
\text { Ganguly, Indroneil; University of Washington } \\
\text { Eastin, Ivan; University of Washington }\end{array}$ \\
\hline Keyword: & $\begin{array}{l}\text { zero inflated model, Lacey Act, Trade Legislation, Wood products' trade, } \\
\text { US-China Trade }\end{array}$ \\
\hline &
\end{tabular}

\section{SCHOLARONEm \\ Manuscripts}


1 A Categorical Modeling Approach to Analyzing the Impacts of the Lacey Act

22008 Amendment on Chinese Companies' Export Cost and the Implications on

\section{Their Sourcing Behaviors}

4

Authors:

6 Ziyi Lu: luz8@uw.edu, CINTRAFOR (Center for International Trade in Forest Product), University of

7 Washington, Seattle, WA 98105, USA.

8

9 Indroneil Ganguly: indro@uw.edu, School of Environmental and Forest Sciences, College of the

10 Environment, University of Washington, Seattle, WA 98105, USA.

11

12 Ivan Eastin: eastin@uw.edu, CINTRAFOR, School of Environmental and Forest Sciences, College of the

13 Environment, University of Washington, Seattle, WA 98105, USA.

14

15 Corresponding author: Indroneil Ganguly (email: indro@uw.edu; telephone: 206-685-8311)

16 


\section{Abstract}

The US Lacey Act 2008 Amendment (LAA) is a timber legality regulation which requires US

19 importers to monitor and minimize the risk of illegally harvested wood products within their supply

20 chains. This paper empirically examines the effect of the LAA on Chinese companies' export costs to the

21 US. The study uses 138 responses from two surveys in Shanghai, China in 2013, 5 years after the LAA

22 was implemented. Given the high proportion of zero export increase indicated by the Chinese

23 companies, a zero-inflated ordered-probit model was used to model Chinese companies' export cost

24 increases to the US. The research results demonstrate that pre-LAA raw material sourcing patterns are

25 primary indicators of the respondents' export cost increase to the US as a result of the LAA. From the

26 results it can be inferred that log and lumber importers from suspect regions are taking additional

27 measures, by changing their procurement practices, to ensure the legality of their raw material which is

28 adding to their cost structure. The results also indicate that smaller companies, given their flexibility

29 with raw material procurement, were less likely to experience a post-LAA cost increase relative to their $30 \quad$ larger counterparts.

31

Key words: Lacey Act, Zero Inflated Model, Trade Legislation, Wood products' trade, US-China 


\section{Introduction}

Illegal logging is a prevalent problem that threatens forest conservation around the world, and thus has come into the spotlight of global forest policy. The problem of illegal logging is especially severe in temperate countries such as China and Russia, that both supply and process wood, as well as in tropical countries (Contreras-Hermosilla et al. 2007). However, the role of consumer countries cannot to be ignored as the demand for wood products in these countries increases the incentives for illegal logging in high-risk countries (Duncan 2005). Recent years have seen a growing familiarity with the issues of illegal logging and the responsibility of consumer countries in helping to develop a solution to illegal logging (Fripp 2006).

The US Lacey Act 2008 Amendment (LAA) was the first and remains one of the most important timber legality regulations because it requires US importers to monitor and minimize the risk of illegally harvested wood products within their supply chains. The LAA was the world's first ban on the trade of illegal wood, a precedent in the fight to eliminate the trade of illegallyharvested wood and wood products (EIA 2009). The LAA was designed to eliminate imports of illegally-harvested wood products and requires that importers document the foreign sources of wood-based products (Wang et al. 2010). US companies are required to practice "due care" under the LAA in order to guard against liability (EIA 2010); although it is important to note that it is the responsibility of the US Government to enforce the LAA. Failure to comply with the LAA can result in civil administrative penalties, forfeiture of the imported goods, criminal fines, or imprisonment. As one of the major importers of forest products in the world, most of the efforts that the US has taken to tackle illegal logging and deforestation are related to the 
57 implementation of the LAA (Lawson and McFaul 2010). Inspired by the LAA and its ability to 58 cover all countries simultaneously, the EU Council and Parliament adopted the "EU Timber 59 Regulation" in 2010, which also requires importers to avoid illegal timber (Cashore and Stone 60 2012).

Most of the previous studies assessing the impacts of the LAA on trade flows at the

62 macro level have acknowledged the positive effects of the Lacey Act on curbing illegal logging

63 (Bridegam 2014; Gan et al.2013; Prestemon 2015). This paper employs a micro-level analysis

64 and explores the impacts of the LAA on exporting companies in China, the largest supplier of

65 wooden furniture and flooring in the world and the second largest exporter of wood products

66 to the US. China is in the world's spotlight regarding its impact on forests and forest industries

67 globally given its role as the largest importer and exporter of wood products in the world

68 (White et al. 2006). China's furniture and flooring industry is heavily dependent on imported

69 logs and lumber as a raw material input (Ganguly and Eastin 2011). Moreover, China is the

70 largest purchaser of illegal wood from many of the countries that have been affected by the

71 scourge of illegal, and most of China's wood product manufacturers source their wood

72 materials from countries where illegal harvesting and other legal violations have been well

73 documented (Gregg and Porges 2008). As a result, there are potential risks that wood products

74 manufactured in China might be manufactured in part or wholly from illegally harvested wood,

75 which is addressed by the LAA as a trade measure.

76 Given the large volume of trade in wood products between China and the United States,

77 the LAA plays an important role in the flow of wood products between these two countries.

78 This paper is interested in investigating the effect of the LAA on Chinese companies' 
79 international competitiveness by examining its impact on Chinese companies' export costs.

Although the LAA does not intend to increase the cost of exports, it requires Chinese companies to do more paperwork in order to keep track of and declare the species, quantity, value, and origin of wood used in their products (as required in the Plant Product Declaration Form 505).

These additional documentation requirements are burdensome and can impose substantial costs on companies, particularly small-sized firms ( Cashore and Stone 2012; Tanczos 2011).

The LAA may create a strong incentive for Chinese companies exporting to the US to reduce additional paperwork by importing wood raw materials from legal sources (e.g., the US, Canada, the EU and other lower-risk/non-suspect countries) (Wang et al. 2010). Strong international competition leads to a heightened cost sensitivity by exporters (Carlin et al. 2001) and purchasing legal wood products is likely to be more expensive than their illegal alternatives (Tacconi 2007), potentially adding to export costs. Some literature indicates that the LAA has impacted the forest-product trade between China and the US by raising production and export costs for Chinese companies, thereby reducing the Chinese companies' international competitiveness (Wu et al. 2009).

The objective of this research is to empirically verify whether Chinese companies' export costs to the US have increased because of the LAA, and to identify the impact of the LAA on the material sourcing behavior and other specific characteristics of Chinese companies that may cause or contribute to an export cost increase. Three research questions are addressed: (i) has the LAA resulted in a cost increase for Chinese wood exporters, (ii) if so, what type of sourcing activities have contributed to the export cost increase, and (iii) what are the characteristics of the companies that reported export cost increases? 


\section{Methods}

102 Survey and Data Preparation

103 Data for this study was collected using a structured questionnaire administered at two 104 trade shows in Shanghai, China. The first trade show was the DOMOTEX Asia/CHINAFLOOR 105 Show in March 2013, and the second was the FMC China (Furniture Manufacturing \& Supply 106 China) trade show in September 2013. There were 40,000 visitors and 1,100 exhibitors in the 107 DOMOTEX Asia/CHINAFLOOR 2013 Show, and 33,834 visitors and 790 exhibitors in the FMC 108 China 2013 Show. These shows were selected for the survey because they are the largest wood flooring and wood furniture trade shows in China. The DOMOTEX Asia/CHINAFLOOR is the 110 largest international flooring trade exhibition in the Asia-Pacific region (China Exhibition 2013).

111 FMC China is the third largest furniture show in the world and the leading furniture trade show 112 in China (10times 2013). The convenience sampling method was adopted for the surveys as it is 113 a cost effective way to survey a readily available target population (Greene 1981). Given the 114 sampling method adopted, the selection of survey venue is critical for ensuring the 115 representativeness of the target population. Hence, the selection of the two most influential 116 international wood furniture/flooring trade shows in China ensured strong industry 117 representation from the dominant wood products manufacturing and trading regions of the 118 country.

A total of 226 valid questionnaires were collected, 106 from the DOMOTEX 120 Asia/CHINAFLOOR show, and 120 from FMC China show, representing respondents from 20 out 121 of 34 provinces and regions in China. Moreover, the survey had high representation from all of 122 the five forest-product manufacturing centers in China (China wood group Co., Ltd 2014), 123 located in (i) the Pearl River region, (ii) the Yangtze River region, (iii) the Bohai Sea region, (v) 
124 the Northeastern region, and (v) the Southwestern region. Out of 172 respondents who 125 indicated that they were aware of the LAA, 154 responded to the question of whether they 126 have had an export cost increase due to the LAA. We deleted another 16 respondents who have 127 no sales to the US market, as this study aims at examining the direct impacts of the LAA on the 128 companies who have sales to the US. This resulted in a total of 138 valid responses, of which 47 129 (34\%) respondents reported that they did not have an export cost increase.

130 The companies who indicated nonzero export cost increases were then asked to 131 estimate the percentage of their export cost increase as a result of the LAA. The answers to this 132 question displayed a high proportion of responses that were multiples of $5 \%$. Such rounding 133 suggests that the percentage values indicated by most of the respondents are likely to be 134 approximate values. Hence, instead of using the actual percentage values, the percentage135 increase variable of the export cost was monotonically transferred into four ordinal levels of 136 export cost increases (Winship and Mare 1984) as was used in Ganguly et al. (2010). The four 137 categories, or levels, of the export cost increases were: 1) no increase with a variable value equal to $0 ; 2$ ) small cost increase (between $>0$ and $\leqslant 5 \%$ ) with a variable value equal to $1 ; 3$ )

139 moderate cost increase $(>5 \%$ and $\leqslant 10 \%)$ with a variable value equal to 2 ; and 4 ) large cost 140 increase $(>10 \%)$ with a variable value equal to 3.

In the survey, inquiries about the companies' sourcing regions included Russia, the US,

142 Canada, Southeast Asia, Africa, the European Union (EU), Latin America and China. These 8 143 regions are mutually exclusive and respondents were asked whether they had sourced wood 144 from these regions. For modeling purposes, an exploratory factor analysis was conducted to 145 reduce the dimensions of the data and to eliminate the multi-collinearities among the regional 
146 procurement variables (Lattin et al. 2003). The Kaiser stopping criterion is used to decide how 147 many factors to extract based on all factors with eigenvalues greater than 1 (Kaiser 1958). 148 Varimax rotation was used to facilitate the interpretation of the factor analysis results by 149 maximizing the sum of the variances of the squared loadings, or the squared correlations 150 between variables and factors (Abdi 2003), Table 1. Finally an orthogonal solution is obtained 151 by varimax rotation as new variables for regression. The factor analysis reduced the original 8 152 regions to 3. The first group is composed of the US, Canada, EU, and Russia. These countries are 153 in temperate regions dominated by temperate softwood, and thus form the "sourcing from 154 temperate regions" group. The second group is composed of Southeast Asia, Latin America and 155 Africa. These countries are in the tropical regions dominated by tropical hardwood, and thus 156 form the "sourcing from tropical regions" group. The third group is composed only of China, 157 and is called the "sourcing from local China" group. Companies who are required to change 158 their sourcing region may experience an increase in the cost of raw material imports as a result 159 of LAA compliance (Wang et al. 2010; Prestemon 2015). For the three groups identified, the factor scores were obtained as composite variables 161 which provide information about an individual's placement on the factor as well as being used 162 as variables in subsequent modeling (DiStefano et al. 2009). The factor scores are standardized 163 results, so the new variables for "sourcing from temperate regions," "sourcing from tropical 164 regions" and "sourcing from local China" range from -3 to 3 with a mean of 0 . A high value for a 165 factor score means that the respondent possesses multiple sources from the sourcing group, 166 and a low value indicates single or no sourcing from that group. 
167

168

169

170

171

172

173

174

175

176

177

178

179

180

181

182

183

184

185

186

187

188

\section{Zero Inflated Ordered Probit (ZIOP) model specification}

With regards to the sourcing activities associated with the Chinese companies' export cost increase, this study explores the Chinese companies' raw material sourcing patterns since the introduction of LAA, and the impact of any changes in these sourcing patterns on their export costs. The two specific aspects of raw material sourcing considered in the models are: (i) the respondents' use of chain-of-custody $(\mathrm{CoC})$ certification for material sourcing, and (ii) the respondents' sourcing of raw material from different regions of the world. The corresponding independent variables are obtained from the survey and are presented in table 2.

In China, certification favored by timber legality legislation such as the LAA is increasingly seen as a means to protect the timber processing industry's position within the global market (Putzel 2009). The implementation of the LAA is likely to encourage the spread of private certification and legality verification systems (Brack and Buckrell 2011). In addition, the illegal logging issues and associated trade are highly suspicious in tropical areas (Glastra 1999), and tropical hardwood receives the most attention with respect to illegal activity (Seneca Creek 2004). The LAA seeks to discourage the trade in illegally harvested wood and may indirectly affect imports from suspect countries (Prestemon 2015) particularly those in tropical regions. At the same time, there is a very low risk of US hardwoods and softwoods being derived from illegal or controversial sources (Goetzl and Ekström 2007). To export finished wood products to the US market, Chinese companies may be encouraged by the LAA to import wood raw materials from the US and other reliable and low-risk sources (Wang et al. 2010). Given this situation, the model seeks to discover the impacts of the Chinese companies' adoption of CoC certification, as well as changes in their supply chains, on their export costs. 
With regards to the characteristics of the companies that reported export cost increases,

190

191

192

193

194

195

196

197

198

199

200

201

202

203

204

205

206

207

208

209

210

the model takes into account the Chinese companies' familiarity with the LAA, company size, and industry type: wood flooring versus wood furniture (table 2). We assume that the companies' familiarity with the LAA may affect their export costs. The company's size and industry type are factors that are frequently analyzed in the business field as well as in the forest product marketing research. Previous research indicates that under market pressure, small and mid-sized manufacturing enterprises (SMEs) are not motivated to undertake voluntary actions for the benefit of wider stakeholders and society, so regulations have a vital part to play in improving the environmental and social practices of SMEs; SMEs will generally try to comply with, but not go beyond, environmental regulations (Williamson et al. 2006). Previous general business research also reveals that inducing firms to adopt corporate environmentalism requires the use of different agents of influence according to industry type; where the industry type moderates the influences of public concern, regulations, and competitive advantages on top managers (Banerjee et al. 2003).

In this research the dependent variable, Chinese companies' export cost increase due to the LAA, is grouped into four levels indicating the extent of the Chinese companies export cost increase to the US (Table 2). In the case of ordinal variables, the categories are ranked in an increasing/decreasing order, however, the relative distances between adjacent categories are unknown (Long 1997). Accordingly, the classical regression approach assuming a scalar dependent variable is not appropriate for categorical dependent variable (Liao 1994). This study first employs an ordinal probit modeling approach for estimating the relationship between the ordinal and discrete dependent variable and the independent variables previously described. 
211 For a standard ordered probit model, a single latent variable, $\mathrm{y}^{*}$, ranging from $-\infty$ to $\infty$ is 212 mapped to an observed variable y (Long 1997).

$$
\begin{aligned}
& y_{i}=m \text { if } \mu_{m-1} \leq y_{i}^{*}<\mu_{m} \text { for } \mathrm{m}=1 \text { to } \mathrm{j} \\
& y_{i}^{*}=\beta^{\prime} x_{i}+\varepsilon_{i}, i=1,2, \ldots, n
\end{aligned}
$$

Where, the $\mu^{\prime} s$ are the thresholds or cutpoints between the categories and $\mathrm{j}$ is the total 215 number of categories for the ordinal variable. For each observation $i, y_{i}^{*}$ is the latent-response 216 variable of interest, $x_{i}$ is a vector of the independent variables, $\beta^{\prime}$ is a vector of parameters, $\varepsilon_{i}$ 217 is a random disturbance term, and $y_{i}^{*}$ is unobserved and is considered as the underlying 218 tendency of the observed phenomenon $y_{i}$. We assume that $\varepsilon_{i}$ follows a normal distribution 219 with zero mean in the probit modeling approach. In addition, the discrete ordered dependent variable has another distinguishing feature

221 in that $47(34 \%)$ of 138 respondents indicated that they did not observe a cost increase, which 222 suggests that there may be an "excessive" number of zero observations. Failure to account for 223 the extra zeros may result in biased parameter estimates and misleading inferences (Lee et al. 224 2006). In addition, these "excessive" zero observations of the dependent variable may be 225 driven by two different systems of individual behavior. Hence, to address the econometric 226 issues in which the dependent variable is characterized by excessive zeros related to two 227 distinct data generating processes, a zero-inflated model is suggested in the literature (Greene 228 1994). In this research, the zero-inflated ordered probit model is used as a comparison with the 229 standard ordered probit model to investigate the Chinese companies' export cost increase 230 under the context of the LAA. 
Since its enactment in 2007, the LAA has only been enforced twice: two individual cases

232 against the Gibson Guitar Corporation concerning the import of ebony wood from India and 233 Madagascar (Pryce 2012), and the seizure of Peruvian hardwood from the Amazon (Nogueron 234 and Hanson, 2010). While the LAA imposes severe penalties on companies caught importing 235 illegally harvested wood, it doesn't necessarily detect or eradicate all illegally sourced wood 236 from the supply chain. Some companies that are not sourcing completely legally may not be 237 impacted by the LAA or suffer from an export cost increase. Therefore, the first type of zero 238 cost increase would be reported by companies who have always had legal sourcing and are thus 239 unaffected by the LAA. Specifically in case of a cost increase associated with the LAA, 240 companies who are stochastically associated with the first type of zero, in a zero-inflated model, 241 form a cohesive group and are not likely to report a LAA-related increase in their export cost 242 under a different condition. The model stochastically assigns some respondents who have 243 reported no increase in their export cost to the second group, because their characteristics 244 align with the non-zero responders, and they are statistically more likely to report an increase 245 in their export cost under a different situation or in the near future. In other words, companies 246 who are assigned to the second type of zero group exhibit characteristics similar to other 247 companies who reported experiencing an actual export cost increase.

248 The zero-inflated ordered probit model (ZIOP) is an extension of the standard ordered 249 probit model, with an ordinal-probit equation nested within a splitting-probit equation (Harris 250 and Zhao 2007). The ZIOP model involves a system of a probit "splitting" model and an OP 251 model which relate to potentially differing sets of covariates. This model splits the observations 252 into two regimes so that the Chinese companies in this research are modeled as overcoming 
253 two hurdles: whether their export costs have increased or not, and then, conditional on the 254 situation of increased export cost, the levels of the export cost increase. Companies who have 255 no export cost increase fall into Regime 0 , and companies who have an export cost increase 256 (actual and potential) fall into Regime 1. The split between Regime 0 and Regime 1 is indicated 257 by $r$, where $r=0$ indicates zero export cost increase (regime 0 ), and $r=1$ indicated an actual or 258 potential export cost increase (regime 1). Within Regime 1 (where $r=1$ ), export cost increase 259 levels are represented by $\hat{y}$ (in this case $\hat{y}=0,1,2$ and 3 ). Note that, importantly, Regime 1 260 also allows for a zero export cost increase as might be indicated by companies who are in the 261 process of transitioning towards legal sourcing and thus may be incurring a potential export 262 cost increase. Though variables $r$ and $\hat{y}$ are not individually observable, they can be observed 263 through the variable y. For ZIOP, the relationship between the observed variable $y_{i}$ and the 264 latent variable $\hat{y}_{i}^{*}$ and $r_{i}^{*}$ can be stated as follows:

$$
y_{i}=r_{i} \times \hat{y}_{i}^{*}=\left\{\begin{array}{l}
0 \text { if } r_{i}^{*} \leq 0 \text { or } r_{i}^{*}>0, \hat{y}_{i}^{*} \leq 0 \\
1 \text { if } r_{i}^{*}>0 \text { and } 0<\hat{y}_{i}^{*} \leq \hat{\mu}_{1} \\
2 \text { if } r_{i}^{*}>0 \text { and } \hat{\mu}_{1}<\hat{y}_{i}^{*} \leq \hat{\mu}_{2} \\
3 \text { if } r_{i}^{*}>0 \text { and } \hat{\mu}_{2}<\hat{y}_{i}^{*}
\end{array}\right.
$$

The ultimate data-generating process here can be seen as coming from two separate underlying latent variables. The underlying function $r$ is generated by a splitting probit model through the underlying latent function $r^{*}$, and $\hat{y}$ is generated by an ordinal-probit model through the underlying function $\hat{y}^{*}$ as follows:

$$
\begin{aligned}
& r_{i}^{*}=\alpha^{\prime} v_{i}+\varepsilon_{1 i} \\
& \hat{y}_{i}^{*}=\gamma z_{i}+\varepsilon_{2 i}
\end{aligned}
$$

Where,

$271 v_{i} \quad$ is a vector of predictor variables that determines the choice of zero-category regime 
$z_{i} \quad$ is a vector of explanatory variables for determining the levels of export cost increase

Equation (3) can be translated to a set of probability functions in the following form:

$$
\begin{gathered}
\operatorname{Pr}_{j}=\left\{\begin{array}{l}
\operatorname{Pr}(\hat{y}=0 \mid z, v)=\operatorname{Pr}(r=0 \mid v)+\operatorname{Pr}(r=1) \operatorname{Pr}(\hat{y}=0 \mid z, r=1) \\
\operatorname{Pr}(\hat{y}=1 \mid z, v)=\operatorname{Pr}(r=1 \mid v) \operatorname{Pr}(\hat{y}=1 \mid z, r=1) \\
\operatorname{Pr}(\hat{y}=2 \mid z, v)=\operatorname{Pr}(r=1 \mid v) \operatorname{Pr}(\hat{y}=2 \mid z, r=1) \\
\operatorname{Pr}(\hat{y}=3 \mid z, v)=\operatorname{Pr}(r=1 \mid v) \operatorname{Pr}(\hat{y}=3 \mid z, r=1)
\end{array}\right. \\
=\left\{\begin{array}{l}
\left.\operatorname{Pr}(\hat{y}=0 \mid \mathrm{z}, \mathrm{v})=\left[1-\phi\left(-\mathrm{v}^{\prime} \alpha\right)\right]+\phi\left(\mathrm{v}^{\prime} \alpha\right) \phi\left(-\mathrm{z}^{\prime} \gamma\right)\right] \\
\operatorname{Pr}(\hat{y}=1 \mid \mathrm{z}, \mathrm{v})=\phi\left(-\mathrm{v}^{\prime} \alpha\right)\left[\phi\left(\hat{\mu}_{1}-\mathrm{z}^{\prime} \gamma\right)-\phi\left(-\mathrm{z}^{\prime} \gamma\right)\right] \\
\operatorname{Pr}(\hat{y}=2 \mid \mathrm{z}, \mathrm{v})=\phi\left(-\mathrm{v}^{\prime} \alpha\right)\left[\phi\left(\hat{\mu}_{2}-\mathrm{z}^{\prime} \gamma\right)-\phi\left(\hat{\mu}_{1}-\mathrm{z}^{\prime} \gamma\right)\right] \\
\operatorname{Pr}(\hat{y}=3 \mid \mathrm{z}, \mathrm{v})=\phi\left(-\mathrm{v}^{\prime} \alpha\right)\left[1-\phi\left(\hat{\mu}_{2}-\mathrm{z}^{\prime} \gamma\right)\right]
\end{array}\right.
\end{gathered}
$$

277 of the probability of "zero export-cost-increase" companies from the OP process plus the 278 probability of "unaffected" companies from the splitting probit model.

279 Once the full set of probabilities has been specified and given an identically and 280 independently distributed (i.i.d) sample of size $\mathrm{N}$ from the population on $\left(y_{i}, v_{i}, z_{i}\right), i=1, \ldots \ldots . \mathrm{N}$,

281 the parameters of the full model $\left(\beta^{\prime}, \gamma^{\prime}, \mu^{\prime}\right)^{\prime}$ can be consistently and efficiently estimated using

282 maximum likelihood ( $\mathrm{ML}$ ) criteria, yielding asymptotically normally distributed maximum

283 likelihood estimates (MLEs). The log likelihood function is

$$
\iota(\theta)=\sum_{i=1}^{N} \sum_{j=0}^{J} h_{i j} \ln \left[\operatorname{Pr}\left(y_{i}=j \mid v_{i}, z_{i}, \theta\right)\right]
$$

Where the indicator function $h_{i j}$ is

(8) $h_{i j}=\left\{\begin{array}{l}1 \text { if the company has an export cost increase, and the increase level is category } \mathrm{j} \\ 0 \text { if the company is unaffected } \quad(i=1,2, \ldots, \mathrm{N} ; j=1,2, \ldots \mathrm{J}) .\end{array}\right.$ 
285

286

287

288

289

290

291

292

293

294

295

296

297

298

299

300

301

302

303

304

305

306

307

\section{Model Selection and Evaluation}

The log-likelihood function above is maximized to provide model estimates with discrete dependent variables. The maximized value of the log-likelihood function of the full model is the direct and primary indicator of the model's fit (Greene 2002). However, the zero-inflated probit model used in this study incorporates complexity in terms of the number of covariates in the modeling process, which is also an important criterion when comparing the maximized loglikelihood values of the competing models. Various information criteria are used in this study for comparing and selecting the best approximating model among the competing models. Akaike's entropic information criterion (AIC) has had a fundamental impact in statistical model evaluation problems (Bozdogan 1987). The corrected AIC (AICC) method provides a greater penalty for extra parameters, thus providing substantially better selection than AIC (Burnham and Anderson 2002). The Bayesian information criterion (BIC) has become a popular method of model selection in sociological research (Weakliem 1999). While AIC represents the approach of information-theoretic selection based on Kullback-Leibler (K-L) information loss, the BIC represents the other well-known approach of Bayesian model selection based on Bayes factors (Burnham and Anderson 2004). The AIC, AICC and BIC are used in this study for selecting the best approximating model and inferences are drawn using the most appropriate model.

The Vuong test is a hypothesis testing approach for the selection between nested and non-

nested models (Vuong 1989). In this study, the Vuong test is used to test the zero-inflated model against its non-zero-inflated counterpart, the standard ordered probit model (Greene 2002). Vuong's test can be described as a suitably normalized version of the log-likelihood ratio test. Hence, if Vuong's test-statistic is greater than 1.96, the ZIOP is considered a better approximating model than the ordinal probit; whereas, if Vuong's test-statistic is less than - 
1.96, and the ordinal probit is a better approximating model than ZIOP, at the $95 \%$ confidence level. If the test-statistic lies between -1.96 and 1.96, then the models are not statistically distinguishable from each other (Ganguly et al. 2010).

For the purpose of interpretation, the estimated model coefficients are translated into probability values. The effect of each of the significant explanatory variables on the dependent variable is calculated by fixing the values of all other explanatory variables in the model at their respective means and varying the value of the explanatory variable under consideration (Ganguly et al. 2010). To obtain the bootstrapped estimates, 300 simulations were run using the variance-covariance matrix and the parameter estimates for the models. The simulation codes were programmed using $R$ (the $R$ Core Team 2005). To understand the precision of the estimated probability values, single standard-deviation zones, representing $68 \%$ confidence intervals $(\mathrm{Cl})$, are shown around the estimated probability curves.

\section{Results and Discussions}

The sample used for the study consists of 138 respondents from Chinese wood flooring and wood furniture manufacturers. All 138 respondents indicated that they were aware of the LAA and have direct exports to the United States. Of the total respondents, 47 (34\%) respondents indicated that they had no export cost increase due to the LAA. Twenty five (18\%) respondents indicate that their export cost increase was smaller than 5\%, while 36 (26\%) respondents indicated that they had a moderate export cost increase of between $5 \%$ and $10 \%$ and 30 (22\%) respondents indicated that their exports increased by more than $10 \%$. The respondents in the survey were located in 19 of the 34 administrative regions in China. The sample included 50 (36.2\%) small companies, 41 (29.7\%) medium companies and 47 (34.1\%) large companies. A 
330 total of 62 companies (44.9\%) were furniture manufacturers and $43(31.2 \%)$ were flooring

331 manufacturers. The export cost increase of the respondents is modeled using ordinal-probit

332 and zero-inflated ordinal-probit models. The evaluation results are presented in Tables 3 and 4

333 along with the coefficient estimates of each of the covariates, model selection, and evaluation

334 criteria. All of the independent variables are entered twice in the zero-inflated model-once in

335 the splitting section (splitting the zeros) and once in the ordered section. The estimated

336 parameters in the splitting section indicate the role of the covariates in the companies'

337 probability of having an export cost increase because of the LAA, whereas the parameters in

338 the ordered section of the model indicate the role these covariates play in the levels of the

339 export cost increase, if any.

\section{Modeling Results}

The zero-inflated ordinal-probit (ZIOP) model estimates more parameters than the ordinal-

342 probit (OP) model. Thus, the log-likelihood ratio test is biased towards the ZIOP model.

343 However, the corrected Akaike information criteria (AICc) and the Bayesian information criteria

344 (BIC) judge the models by comparing the proximity of the fitted parameter values to those of

345 the true values while adjusting for the number of parameters estimated in the models. In this

346 study, both the AICC and BIC tests favor the ZIOP model as an efficient estimator of the data

347 relative to the OP model, because the BIC and AICC values of the ZIOP model were estimated to

348 be lower than those of the OP model. Hence, the ZIOP model is favored over the OP model as a

349 closer approximation of the 'true' model. It is worth noting that the BIC values of the ZIOP

350 models are lower than that of the OP model by a difference of 38 for the full model and 35 for

351 the best model, indicating strong evidence that the zero-inflated model has done a superior job 
352 of predicting the companies' export cost increase patterns (Weakliem 1999). Further, Vuong's

353 test also favored ZIOP as a better approximating model than OP with p-values less than 0.001,

354 indicating that the nested version of the model (zero inflated model) is a better estimator than

355 its non-nested counterpart (ordinal model). Hence, the zero inflated model was chosen as the

356 model of choice for this study, and the remainder of the paper focuses on the parameter

357 estimates of the ZIOP model. Further analysis is based on the final ZIOP model displayed in

358 Table 4.

The full model (Table 3) includes all the variables of interest. The backward stepwise selection was conducted to find the most parsimonious model with the best AICC and BIC 361 values for the ZIOP models. The independent variables "Industry (flooring versus furniture)," 362 "Hardwood (\%)" and "Domestic Sales (\%)" were not found to be statistically significant and

"LAA: Familiarity," "CoC Certified wood (\%)" and "Sourcing from TEMPERATE/HD/Local Regions

365 (5 years)" are significant in either the splitting or the ordered part of the final ZIOP model. The

366 full model and the final model are robust with the consistent parameter estimates across the

367 models (Table 3 and 4).

\section{Effects of Sourcing Behaviors}

369 The relationship between the Chinese companies' sourcing behaviors and their export cost

370 increase due to the LAA is the fundamental question in this study. The research design of this

371 study allows us to understand the Chinese companies' export cost increase in relationship to

372 their sourcing behaviors from two distinctly different aspects: 1) the influence of the companies'

373 sourcing behaviors on the export cost increase from a binary perspective by distinguishing 
374 between companies that have an export cost increase and those that do not; and 2) the

375 influence of the companies' sourcing behaviors on the various levels of export cost increase for

376 companies that already have an export cost increase. In this study, the variables of the

377 companies' "CoC Certified Wood \%" and the companies sourcing regions such as "Sourcing

378 from Temperate Regions," "Sourcing from Tropical Regions" and "Sourcing from Local China"

379 are statistically significant in the final model results.

380 CoC sourcing: Chain-of-custody certification involves tracking the origin of forest products

381 throughout the supply chain and documenting that products meet specific content

382 requirements (Auld et al. 2008). The splitting section of the model indicates that the companies

383 that source a higher amount of CoC certified wood were more likely to have an export cost

384 increase, as evidenced by the significant estimated parameter for "CoC Certified Wood \%" at

385 the $95 \%$ confidence level. However, there is no evidence that the levels of the companies'

386 export cost increase are associated with the companies' usage of CoC certified wood, with an

387 insignificant parameter for "CoC Certified Wood \%" in the ordered part. As can be observed in

388 the first panel of Figure 1 (Panel 1.1), the probability of having a higher export cost increases as

389 the companies utilize more CoC certified wood. This suggests that Chinese companies regard

390 CoC certification as an extra export cost brought about by the LAA. Given the fact that the LAA

391 is a fact-based rather than a document-based statute (EIA, 2010), the CoC certificates are

392 neither proof of legality nor required by the LAA. However, documents such as CoC certificates

393 contribute toward demonstrating due care in assessing legality. From the model results, it can

394 be inferred that as a result of the LAA, Chinese companies tend to increase their use of CoC 395 certification. 
Sourcing from Temperate Regions: The results obtained for the role of "sourcing from temperate regions" show that both coefficients of this particular covariate in the splitting section and the ordered section are significant. However, the coefficient estimate for the splitting parameter is significantly negative while that of the ordered parameter is significantly positive (Table 4). This result indicates that the companies with more sourcing from temperate regions are less likely to have an export cost increase. However, among the companies that 402 have indicated an export cost increase, those using multiple temperate sourcing regions are more likely to indicate a higher level of export cost increase than those using fewer temperate sourcing regions.

In Figure 2 the first panel (Panel 2.1) indicates that the respondents with no raw material sourcing from "temperate regions" are more likely to indicate a cost increase as a result of the

407 LAA relative to companies with sourcing from temperate regions. The negative slope in the 408 splitting section of the model (Panel 2.1) indicates that if a company has established sourcing routes from temperate regions they are less likely to be required to make any sourcing changes as a result of the LAA and therefore their export costs are less likely to increase.

Panel 2.2 represents the minority of the respondents that import raw material from

412 temperate regions but who have reported having a cost increase. The steep positive slope of 413 the 'notable increase' curve in this section indicates that respondents resorting to multiple 414 sources within the temperate region have a higher likelihood of indicating a notable cost 415 increase as a result of the LAA. This may be due to the fact that the importers need to ensure 416 proper documentation from all their suppliers across multiple sourcing regions, which may add 417 to their export costs. 
Sourcing from Tropical Regions: For sourcing from tropical regions, there is a positive and

419

420

421

422

423 424 countries.

425

426

427

428

429

430 significant coefficient estimate of "sourcing from tropical region" in the splitting section of the model. In Figure 3, Panel 3.1 shows that when companies have more sourcing from tropical regions they are more likely to have an export cost increase. Under the context of the LAA, sourcing from tropical regions is more likely to result in an export cost increase. This modeling result provides evidence that the LAA may be effective at discouraging imports from suspect

Sourcing from China: In the case of "Sourcing from Local China," there is no evidence that the Chinese companies' sourcing from local China has an effect on their export cost increase in the splitting (increase versus no increase) section, as the estimated parameter is not significant (Table 4). However, the significant parameter for "Sourcing from Local China" in the ordered section of the model indicates that for companies who have already experienced an export cost increase, the levels of their export cost increase lessen with more sourcing from local China. In Fig. 4 Panel 4.2, the probability that the Chinese companies will have a notable export cost increase goes down when the companies increase their sourcing from China's domestic market. This implies that sourcing from local China can help Chinese companies avoid a high level of export cost increase to the US which may reflect the convenience of acquiring document/paperwork and CoC certificates in China.

\section{Effects of Companies' Demographic Characteristics}

Similar to the analysis of the companies' sourcing behaviors, there are two possible ways of interpreting the companies' export cost increases given certain characteristics of the companies: determining whether the characteristics of the companies tend to cause an export cost increase, 
440 and whether these characteristics raise the level of the export cost increase. The predictor

441 variable of the companies' characteristics is included twice in the model, first as a covariate in

442 the splitting section of the model and second in the ordered part. The splitting section

443 differentiates between companies who have an export cost increase and companies who do

444 not based on their characteristics. The ordered part predicts levels of export cost increase

445 influenced by the firm's characteristics. According to the model results presented in Table 4, 446 the "size of the company" and "LAA Familiarity" both proved to be significant.

In the case of "Size of the Company," it can be observed that the coefficient estimate in the

448 splitting section of the model is significantly $(p<0.05)$ positive. This indicates that larger

449 companies are more likely to have an export cost increase. The parameter estimate for "Size of

450 the Company" is not statistically significant in the ordered section of the model. This indicates

451 that for companies who already have an export cost increase, companies of all sizes are equally

452 likely to have an export cost increase at any level. Fig. 5 clearly demonstrates that smaller

453 companies are more likely than big companies to have no export cost increase. This may be due

454 to the fact that smaller companies have greater flexibility to adjust to the requirements of the

455 LAA, and their subsequent ease and ability to shift to activities favored by the LAA.

456 The coefficient for the variable "LAA: Familiarity" is significantly negative at the splitting

457 section of the model. Data demonstrates that companies that are not familiar with the LAA are

458 more likely to have an export cost increase than are companies that are familiar with the LAA.

459 In the ordered section, the statistically insignificant coefficient for the variable "LAA: Familiarity"

460 indicates that the export cost increase levels for companies familiar/not familiar with the LAA

461 are not differentiable. 


\section{Conclusions}

463 This research provides useful insights regarding the impact of the Lacey Act 2008

464 Amendment (LAA) on Chinese wood products exporters. The results obtained from the zero 465 inflated ordered probit model indicate that the impact of the LAA on Chinese wood products

466 export costs are dependent on the procurement practices and the demographic characteristics 467 of the companies. Empirical evidence suggests that the LAA has affected the Chinese companies' 468 export costs to the US market to varying degrees. In the context of the LAA, both the sourcing 469 behaviors and the sourcing characteristics of the Chinese companies are factors that influence 470 their export cost increases.

471 The modeling results also indicate that if a company has established sourcing routes from 472 temperate regions, they do not feel the need to make any sourcing changes as a result of the 473 LAA, and their export cost is not adversely affected. Conversely, the probability of an export 474 cost increase because of the LAA is higher for companies who primarily source their raw 475 materials from tropical regions. Using these results, we can infer that the LAA is likely to 476 provide a comparative advantage to forest product companies located in the temperate regions, 477 including the US. Similarly, the LAA places the forest product industry located in tropical regions 478 at a competitive disadvantage. The Chinese respondents who primarily source raw material 479 from domestic China indicated lower export cost increases as a result of the LAA, which may be 480 due to the convenience of acquiring the LAA compliance paperwork in China. However, the 481 Chinese domestic sourcing of wood raw material by the furniture and flooring industry cannot 482 meet the demand of Chinese manufacturers in the near future. Given a series of Chinese 483 domestic policies such as the National Forest Protection Program to restore forest base, 
484 domestic wood production in China has been kept low and will not be able to satisfy the 485 sourcing needs of Chinese companies (White et al. 2006).

486 During the interviews in China the researchers got an overwhelming sense that 487 respondents perceive that chain-of-custody certification, (both through the FSC and PEFC 488 programs), is one of the ways to comply with the LAA. The modeling results support this 489 anecdotal information. The Chinese respondents who use a higher percentage of CoC certified 490 raw material procurement are more likely to report an increase in export costs as a result of the 491 LAA. This may be due to the fact that the additional procurement costs associated with CoC 492 certified raw material are considered to be a cost of complying with the LAA. However, while it 493 may be easier to prove compliance if the manufacturers use CoC certified wood, it is important 494 to note that the use of CoC certified wood is neither necessary nor sufficient to demonstrate 495 LAA compliance (EIA 2009). With regards to the demographic characteristics of the companies, 496 the smaller sized manufacturers/exporters are less likely to experience a post-LAA cost increase 497 relative to their larger counterparts. This follows the basic principles of economics, where 498 smaller companies are more adaptable to changing market conditions (Ganguly et al. 2010) and 499 are better able to adjust to the requirements of the LAA. 
501 We gratefully acknowledge the support of the USDA Federal State Marketing Improvement 502 Program (FSMIP), award no. 12-25-G-1519 and the Mclntire-Stennis Formula Fund for providing 503 financial support to this study. We also thank the Softwood Export Council for funding the 504 international travel, and the American Hardwood Export Council for their help with the data 505 collection. 


\section{References}

10times.com. 2013. Citing online sources: Furniture Manufacturing \& Supply China [online]. Available from http://10times.com/ furniture-manufacturing-supply

Abdi, H. 2003. Factor rotations in factor analyses. In Encyclopedia of Social Science Research Methods. Edited by M. S. Lewis-Beck, A. Bryman. and T. Futing Liao. Sage Publications, Inc. Thousand Oaks, CA. Auld, G., Gulbrandsen, L. H., and McDermott, C. L. 2008. Certification Schemes and the Impacts on Forests and Forestry. Annu Rev Environ Resour. 33, 187-211. doi:10.1146/annurev.environ.33.013007.103754

Banerjee, S. B., Iyer, E. S., and Kashyap, R. K. 2003. Corporate Environmentalism: Antecedents and Influence of Industry Type. J. Marketing. 67(2), 106-122. doi:10.1509/jmkg.67.2.106.18604

Bozdogan, H. 1987. Model selection and Akaike's information criterion (AIC): The general theory and its analytical extensions. Psychometrika, 52(3), 345-370.

Brack, D., and Buckrell, J. 2011. Controlling Illegal Logging: Consumer-Country Measures. Energy, Environment and Resource Governance, Chatham House. Available from http://www.illegallogging.info/sites/default/files/uploads/CHIllegalLoggingConsumerCountryMeasuresWEB.pdf

Bridegam, P. 2014. The Effects of the 2008 Lacey Act Amendment on International Trade in Forest Products. M.Sc. Thesis. School of Environmental and Forest Sciences, University of Washington, Seattle, US.

Burnham, K. P. and Anderson, D.R. 2002. Model selection and multimodel inference: a practical information-theoretic approach.2nd ed. Springer Science \& Business Media LLC, NY.

Burnham, K. P., and Anderson, D. R. 2004. Multimodel inference understanding AIC and BIC in model selection. Social. Method. Res. 33(2), 261-304.

Carlin, W., Glyn, A., and Reenen, J. V. 2001. Export market performance of OECD countries: an empirical examination of the role of cost competitiveness. Econ. J. 111(468), 128-162. doi:10.1111/1468-

0297.00592

Cashore, B., and Stone, M. W. 2012. Can legality verification rescue global forest governance? Analyzing the potential of public and private policy intersection to ameliorate forest challenges in Southeast Asia, Forest. Policy. Econ. 18, 13-22. doi: 10.1016/j.forpol.2011.12.005

ChinaExhibition.com. 2013. Citing online sources: The 15th Domotex Asia/China Floor 2013 [online]. Available from http://www.chinaexhibition.com/trade_events/2231-

The_15th_Domotex_Asia/China_Floor_2013.html.

China wood group co., Itd. 2014. Citing online sources: The distribution and advantages of the 5 forest product manufacture centers in China. Available from http://chinawoodgroup.net/hyxw/236.aspx 
Contreras-Hermosilla, A., Doornbosch, R., and Lodge, M. 2007. The economics of illegal logging and associated trade. Organization for Economic Co-operation and Development. Available from http://www.oecd.org/dataoecd/15/43/39348796.pdf

DiStefano, C., Zhu, M., and Mindrila, D. 2009. Understanding and using factor scores: Considerations for the applied researcher. Practical Assessment, Research \& Evaluation, 14(20), 1-11.

Duncan, B. 2005. Controlling illegal logging and the trade in illegally harvested timber: the EU's Forest Law Enforcement, Governance and Trade Initiative. Review of European Community \& International Environmental Law, 14(1), 28-38. doi:10.1111/j.1467-9388.2005.00421.x

Fripp, E. 2006. Illegal Logging and Related Trade: The Global Response and Indicators of Change. Energy, Environment \& Development Programme, Chatham House. Available from http://www.illegallogging.info/sites/default/files/uploads/CHIndicatorsReportFripp.pdf

Ganguly, I., and Eastin, I. 2011. Economic and Environmental Aspects of China's Wood Products Industry. CINTRAFOR News (Winter Issue). Available from http://www.cintrafor.org/publications/newsletter/C4news2011winter.pdf

Ganguly, I., Koebel, T., and Cantrell, R. A. 2010. A categorical modeling approach to analyzing new product adoption and usage in the context of the building-materials industry. Technol. Forecast. Soc. 77(4), 662-677. doi:10.1016/j.techfore.2009.10.011

Gan, J., Cashore, B., and Stone, M. W. 2013. Impacts of the Lacey Act Amendment and the Voluntary Partnership Agreements on illegal logging: implications for global forest governance. Journal of Natural Resources Policy Research, 5(4), 209-226.

Glastra, R. 1999. Cut and run: illegal logging and timber trade in the tropics. International Development Research Center. Available from http://idl-bnc.idrc.ca/dspace/bitstream/10625/25472/6/IDL-25472.pdf

Goetzl, A., and Ekström, H. C. 2007. Report on the Review of the US Market for Tropical Timber Products. International Tropical Timber Organization.

Greene, W. H. 1981. Sample selection bias as a specification error: A comment. Econometrica: Journal of the Econometric Society, 49(3), 795-798.

Greene, W. H. 1994. Accounting for Excess Zeros and Sample Selection in Poisson and Negative Binomial Regression Models. NYU Working Paper No. EC-94-10. Available from SSRN:

http://ssrn.com/abstract=1293115

Greene, W. H. 2011. Econometric Analysis. 7th ed. Prentice Hall, Upper Saddle River, NJ.

Gregg, R. J., and Porges, A. 2008. Amendment to the U.S. Lacey Act: Implications for Chinese Forest Products Exporters. Forest Trends. Available from http://foresttrends.org/documents/files/doc_1316.pdf 
Harris, M. N., and Zhao, X. 2007. A zero-inflated ordered probit model, with an application to modelling tobacco consumption. J. Econometrics. 141(2), 1073-1099.

Illegal Logging and Global Wood Markets: The Competitive Impacts on the U.S. Wood Products Industry. 2004. Seneca Creek Associates, LLC. Poolesville, Md.

Kaiser, H. F. 1958. The varimax criterion for analytic rotation in factor analysis. Psychometrika, 23(3), 187-200.

Lattin, J., Carroll, J. D., and Green, P. E. 2003. Analyzing Multivariate Data. Thomson Brooks/Cole, Pacific Grove, CA.

Lawson, S., and McFaul, L. 2010. Illegal Logging and Related Trade: Indicators of the Global Response. Energy, Environment and Resource Governance, Chatham House. Available from http://www.chathamhouse.org/sites/files/chathamhouse/public/Research/Energy,\%20Environment\%20 and\%20Development/0710bp_illegallogging.pdf

Lee, A. H., Wang, K., Scott, J. A., Yau, K. and McLachlan, G. J. 2006. Multi-level zero-inflated Poisson regression modelling of correlated count data with excess zeros. Stat. Methods. Med. Res. 15(1), 47-61. doi: 10.1191/0962280206sm429oa

Liao, T. F. 1994. Interpreting Probability Models: Logit, Probit, and Other Generalized Linear Models, Sage University Paper series on Quantitative Applications in the Social Sciences Series. No. 101.

Long, J. S. 1997. Regression Models for Categorical and Limited Dependent Variables. Sage Publications, Inc. Thousand Oaks, CA.

Nogueron, R., and Hanson, C. 2010. Citing online sources: Risk Free? Paper and the Lacey Act [on line]. World Resource Institute. Available from http://www.wri.org/blog/2010/11/risk-free-paper-and-laceyact

Prestemon, J. P. 2015. The impacts of the Lacey Act Amendment of 2008 on U.S. hardwood lumber and hardwood plywood imports. Forest. Policy. Econ. 50, 31-44. doi:10.1016/j.forpol.2014.10.002

Pryce, M. 2012. Reason to fret: how the Lacey Act left the music industry singing the blues. Rutgers. Law. Rev. 65, 295.

Putzel, L. 2009. Upside-down: Global forestry politics reverses directions of ownership in Peru-China timber commodity chains. XIII World Forestry Congress, Buenos Aires, Argentina.

The R Core Team, 2005. R: A Language and Environment for Statistical Computing. R Foundation for Statistical Computing, Vienna , Austria. Available from http://www.R-project.org.

Tacconi, L. 2007. Illegal Logging: Law Enforcement, Livelihoods and the Timber Trade. Earthscan, London, UK 
Tanczos, F. 2011. A New Crime: Possession of Wood - Remedying the Due Care Double Standard of the Revised Lacey Act. Rutgers. Law. Rev. 42(549).

Environmental Investigation Agency. 2009. The U.S. Lacey Act Frequently Asked Questions about the World's First Ban on Trade in Illegal Wood [online]. Available from http://issuu.com/eiaglobal/docs/eia.laceyreport.english/1?e=7348194/1879867

Vuong, Q. H. 1989. Likelihood ratio tests for model selection and non-nested hypotheses. Econometrica, 57(2), 307-333.

Wang, J., Wu, J., DeVallance, D. B., and Armstrong, J. P. 2010. Appalachian Hardwood Product ExportsAn Analysis of the Current Chinese Market. Forest. Prod. J. 60(1), 94.

Weakliem, D. L. 1999. A critique of the Bayesian information criterion for model selection. Sociol. Method. Res. 27(3), 359-397.

White, A., Sun, X., Canby, K., and Xu, J. 2006. China and the Global Market for Forest Products: Transforming Trade to Benefit Forests and Livelihoods [online]. Forest Trends. Available from http://www.forest-trends.org/documents/files/doc_103.pdf

Williamson, D., Lynch-Wood, G., and Ramway, J. 2006. Drivers of environmental behavior in manufacturing SMEs and the implications for CSR. J. Bus. Ethics. 67(3), 317-330. doi: 10.1007/s10551006-9187-1

Winship, C., and Mare, R. D. 1984. Regression models with ordinal variables. Am. Sociol. Rev. 49(4), 512525.

Wu, B., Zhang, L., and Yu, T. 2009. Influence of Lacey Act on Sino-USA Forest Product Trade and Its Countermeasures. Forestry Economics, 1, 019. (in Chinese) 


\section{Tables}

506

507

\begin{tabular}{llll}
\hline & $\begin{array}{l}\text { Softwood } \\
\text { Dominant } \\
\text { Regions }\end{array}$ & $\begin{array}{l}\text { Hardwood } \\
\text { Dominant } \\
\text { Regions }\end{array}$ & $\begin{array}{l}\text { China } \\
\text { Local }\end{array}$ \\
\hline $\begin{array}{l}\text { Russia } \\
\text { US }\end{array}$ & $\begin{array}{l}0.683 \\
\text { Canada }\end{array}$ & 0.809 & \\
EU & 0.77 & & \\
SE Asia & 0.794 & & \\
Africa & & 0.817 & \\
S. America & & 0.775 & \\
China & & 0.555 & \\
\hline
\end{tabular}


Table 2. Introduction of the variables

\begin{tabular}{|c|c|c|c|}
\hline & name of variable & variable description & $\begin{array}{l}\text { related survey question and } \\
\text { data manipulation }\end{array}$ \\
\hline $\begin{array}{l}\text { dependent } \\
\text { variable }\end{array}$ & Export Cost Increase & $\begin{array}{l}\text { In the past } 5 \text { years } \\
0: \text { no increase } \\
1: \text { small increase }(\leq 5 \%) \\
2: \text { moderate increase }(5 \%< \\
\leq 10 \%) \\
\text { 3: great increase }(>10 \%)\end{array}$ & $\begin{array}{l}\text { If the respondents were aware } \\
\text { of the Lacey Act Amendment, } \\
\text { they were asked whether and } \\
\text { how much their export cost had } \\
\text { increased due to the } \\
\text { Amendment. Their answered } \\
\text { were grouped into the } 4 \text { groups } \\
\text { as the dependent variable } \\
\text { percentage of coc certified }\end{array}$ \\
\hline \multirow{10}{*}{$\begin{array}{l}\text { independent } \\
\text { variables }\end{array}$} & COC Certified Wood (\%) & continuous variable $\%$ & $\begin{array}{l}\text { raw material } \\
\text { percentage of tropical }\end{array}$ \\
\hline & Hardwood (\%) & continuous variable $\%$ & hardwood raw material \\
\hline & Domestic Sales (\%) & continuous variable $\%$ & percentage of domestic sales \\
\hline & $\begin{array}{l}\text { Industry } \\
\text { furniture }\end{array}$ & & $\begin{array}{l}\text { Companies are asked whether } \\
\text { they are furniture, flooring or } \\
\text { plywood manufacturers, and }\end{array}$ \\
\hline & flooring & $1:$ yes 0 : no & $\begin{array}{l}\text { whether they are exporter or } \\
\text { importer of wooden products. } \\
\text { Level of familiarity with the }\end{array}$ \\
\hline & Lacey Act: Familiarity & $\begin{array}{l}\text { 0: aware but not familiar ; } \\
\text { 1:familiar }\end{array}$ & $\begin{array}{l}\text { Lacey Act. Respondents who are } \\
\text { not aware of the Lacey Act } \\
\text { Amendment are excluded from } \\
\text { this research }\end{array}$ \\
\hline & Size of the Company & $\begin{array}{l}\text { 1: small companies } \\
(2012 \text { revenue }<\$ 6,504,065)\end{array}$ & \\
\hline & & $\begin{array}{l}\text { 2: medium companies } \\
\text { (2012 revenue }<\$ 16,260,163\end{array}$ & company sales revenue in 2012 \\
\hline & & $\begin{array}{l}\text { 3: large companies } \\
\text { (2012 revenue } \geq \$ 16,260,163\end{array}$ & \\
\hline & $\begin{array}{l}\text { Sourcing from SD } \\
\text { Regions } \\
\text { Sourcing from HD } \\
\text { Regions } \\
\text { Sourcing from Local }\end{array}$ & $\begin{array}{l}\text { These three variables are the } \\
\text { results of the explorative factor } \\
\text { analysis for all the } 8 \text { sourcing } \\
\text { regions. They are continuous } \\
\text { variables with standardized } \\
\text { values from }-3 \text { to } 3\end{array}$ & $\begin{array}{l}\text { The companies' sourcing } \\
\text { activities from each of the } \\
\text { regions in the past } 5 \text { years: no } \\
\text { source (0); decrease (1); remain } \\
\text { the same ( } 2 \text { ) and increase ( } 3 \text { ) }\end{array}$ \\
\hline
\end{tabular}

a. SD regions stand for "softwood dominant" regions. In this research, "softwood dominant" regions include the United States, Canada, the European Union and Russia according to the results of the explorative factor analysis.

b. HD regions stand for "hardwood dominant" regions. In this research, "hardwood dominant" regions include Southeast Asia, Africa and South America. 
Table 3. Estimated coefficients for OP and ZIOP models for the impacts of the LAA on the Chinese companies' export cost (full model)

\begin{tabular}{|c|c|c|c|c|}
\hline & \multicolumn{2}{|c|}{ Ordered Probit (OP) } & \multicolumn{2}{|c|}{$\begin{array}{l}\text { Zero-Inflated Order } \\
\text { Probit (ZIOP) }\end{array}$} \\
\hline & Estimates & $p$-value & Estimates & $p$-value \\
\hline \multicolumn{5}{|l|}{ Splitting parameters } \\
\hline Constant & -- & -- & -0.094 & 0.916 \\
\hline \multicolumn{5}{|l|}{ Industry } \\
\hline furniture & -- & -- & 0.366 & 0.557 \\
\hline flooring & & & -0.065 & 0.928 \\
\hline Size of the Company & -- & -- & $0.698 * *$ & 0.042 \\
\hline LAA: Familiarity & -- & -- & $-1.365^{* *}$ & 0.040 \\
\hline COC Certified Wood (\%) & -- & -- & $0.022 *$ & 0.059 \\
\hline Hardwood (\%) & -- & -- & -0.002 & 0.799 \\
\hline Domestic Sales (\%) & -- & -- & -0.011 & 0.180 \\
\hline Sourcing from SD Regions (5 years) & -- & -- & $-0.804 * * *$ & 0.010 \\
\hline Sourcing from HD Regions (5 years) & -- & - & $1.438 * *$ & 0.028 \\
\hline Sourcing from Local (5 years) & -- & -- & 0.175 & 0.555 \\
\hline \multicolumn{5}{|l|}{ Ordered parameters } \\
\hline Constant & 0.131 & 0.759 & 1.871 & 0.002 \\
\hline \multicolumn{5}{|l|}{ Industry } \\
\hline furniture & 0.088 & 0.752 & -0.140 & 0.698 \\
\hline flooring & -0.363 & 0.170 & -0.419 & 0.199 \\
\hline Size of the Company & 0.143 & 0.295 & -0.111 & 0.511 \\
\hline LAA: Familiarity & -0.274 & 0.235 & 0.355 & 0.236 \\
\hline COC wood (\%) & 0.003 & 0.374 & -0.005 & 0.162 \\
\hline Hardwood (\%) & 0.001 & 0.744 & -0.106 & 0.447 \\
\hline Domestic Sales (\%) & -0.001 & 0.861 & 0.006 & 0.455 \\
\hline Sourcing from SD Regions (5 years) & -0.021 & 0.834 & $0.436 * * *$ & 0.001 \\
\hline Sourcing from HD Regions (5 years) & 0.208 & $0.082^{*}$ & -0.106 & 0.447 \\
\hline Sourcing from Local (5 years) & -0.130 & 0.200 & $-0.231^{*}$ & 0.056 \\
\hline Tau 1 & 0.514 & 0.000 & $0.866 * * *$ & 0.000 \\
\hline Tau 2 & 1.237 & 0.000 & $1.820 * * *$ & 0.000 \\
\hline
\end{tabular}

\section{Diagnostics - model evaluation and model selection}

Log Likelihood at maximum

Akaike information criteria (AIC)

Bayesian information criteria (BIC)

AIC Corrected for Sample Size (AICC)

Vuong's test (OP v/s ZIOP)
$-174.4$

374.8

475.7

377.4

Non-nested hypothesis test-statistic:
-155.3 (ZIOP favored) 336.5 (ZIOP favored) 437.5 (ZIOP favored) 339.1 (ZIOP favored)

3.56044 (p-val: 0.0002)

\footnotetext{
- - : not applicable

$*$ : Values are significant at $p<0.1$

$* *$ : Values are significant at $p<0.05$

$* * *$ : Values are significant at $p<0.01$.
} 
Table 4. Estimated coefficients for OP and ZIOP models for the impacts of the LAA on the Chinese companies' export cost (best model)

\begin{tabular}{|c|c|c|c|c|}
\hline & \multicolumn{2}{|c|}{ Ordered Probit (OP) } & \multicolumn{2}{|c|}{$\begin{array}{l}\text { Zero-Inflated Order } \\
\text { Probit (ZIOP) }\end{array}$} \\
\hline & Estimates & $p$-value & Estimates & $p$-value \\
\hline \multicolumn{5}{|l|}{ Splitting parameters } \\
\hline Constant & -- & -- & -0.174 & 0.793 \\
\hline Size of the Company & & & $0.717 * *$ & 0.023 \\
\hline LAA: Familiarity & -- & -- & $-1.500 * * *$ & 0.009 \\
\hline COC Certified wood (\%) & -- & -- & $0.016 * *$ & 0.040 \\
\hline Sourcing from SD Regions (5 years) & -- & -- & $-0.762 * * *$ & 0.002 \\
\hline Sourcing from HD Regions (5 years) & -- & -- & $1.291 * * *$ & 0.008 \\
\hline Sourcing from Local (5 years) & -- & -- & 0.102 & 0.643 \\
\hline \multicolumn{5}{|l|}{ Ordered parameters } \\
\hline Constant & 0.163 & 0.322 & 1.750 & 0.000 \\
\hline Size of the Company & 0.085 & 0.504 & -0.160 & 0.313 \\
\hline LAA: Familiarity & -0.227 & 0.312 & 0.423 & 0.133 \\
\hline COC wood (\%) & 0.003 & 0.338 & -0.005 & 0.191 \\
\hline Sourcing from SD Regions (5 years) & -0.017 & 0.861 & $0.416 * * *$ & 0.002 \\
\hline Sourcing from HD Regions (5 years) & $0.172 *$ & 0.094 & -0.177 & 0.151 \\
\hline Sourcing from Local (5 years) & -0.116 & 0.238 & $-0.237 * *$ & 0.050 \\
\hline Tau 1 & 0.504 & 0.000 & 0.849 & 0.000 \\
\hline Tau 2 & 1.217 & 0.000 & 1.775 & 0.000 \\
\hline
\end{tabular}

Diagnostics - model evaluation and model selection

Log Likelihood at maximum

Akaike information criteria (AIC)

Bayesian information criteria (BIC)

AIC Corrected for Sample Size (AICC)

Vuong's test (OP v/s ZIOP)

$\begin{array}{ll}-176.2 & -158.8 \text { (ZIOP favored) } \\ 370.3 & 335.5 \text { (ZIOP favored) } \\ 440.2 & 405.4 \text { (ZIOP favored) } \\ 371.5 & 336.7 \text { (ZIOP favored) }\end{array}$

Non-nested hypothesis test-statistic:

3.435662 ( $p$-val: 0.0003)

\footnotetext{
- - : not applicable

$*$ : Values are significant at $p<0.1$.

**: Values are significant at $p<0.05$

$* * *$ : Values are significant at $p<0.01$
} 
Figure captions

Fig. 1 Relation between CoC Certificates Adoption and Export Cost Increase

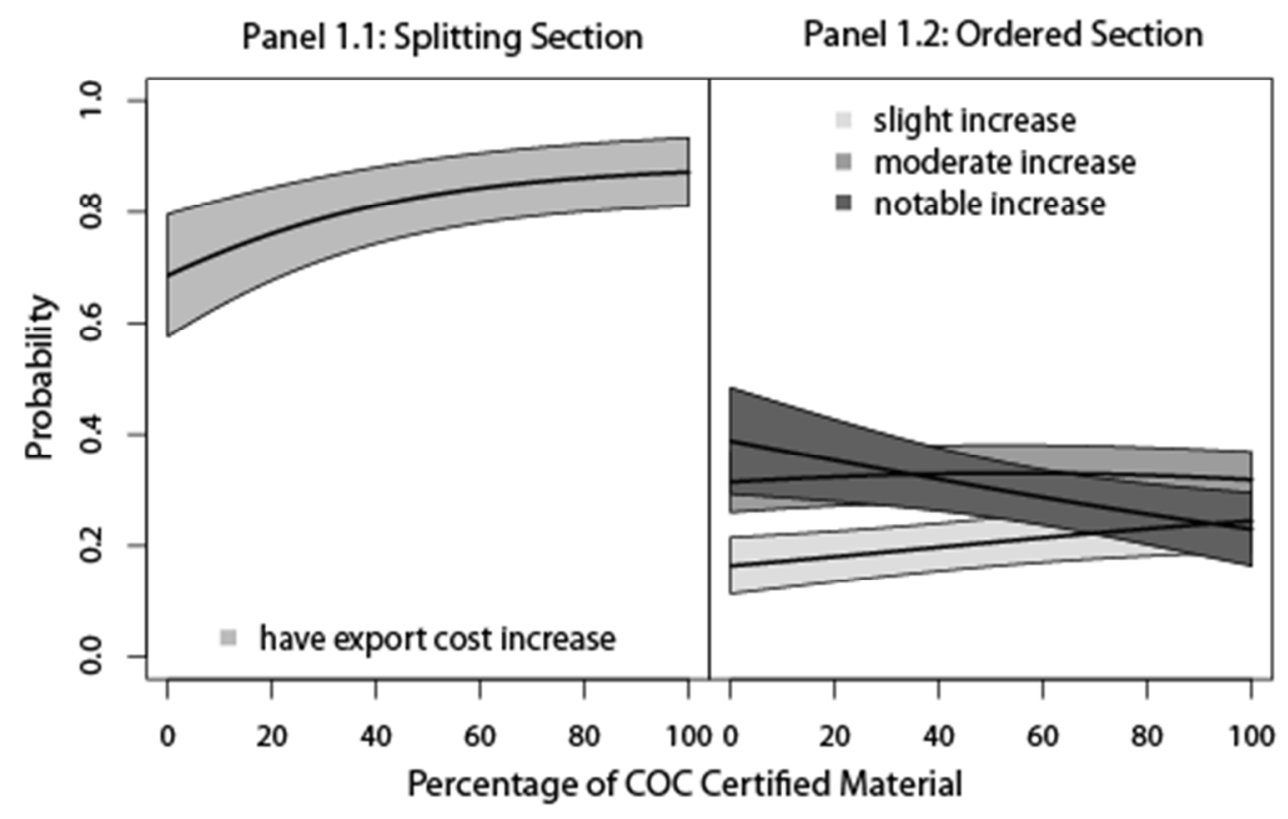


Fig.2 Relation between Sourcing from Temperate Regions and Export Cost Increase

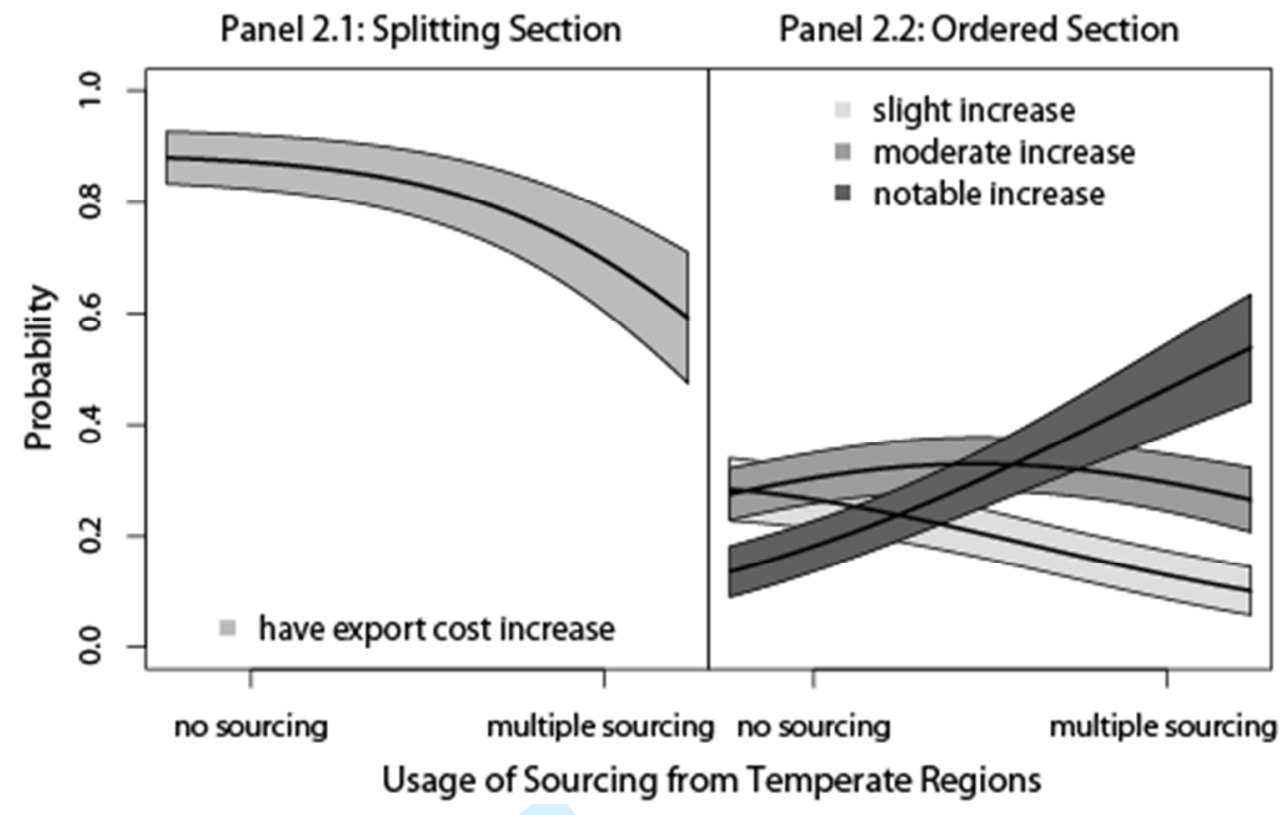


Fig.3 Relation between Sourcing from Tropical Regions and Export Cost Increase

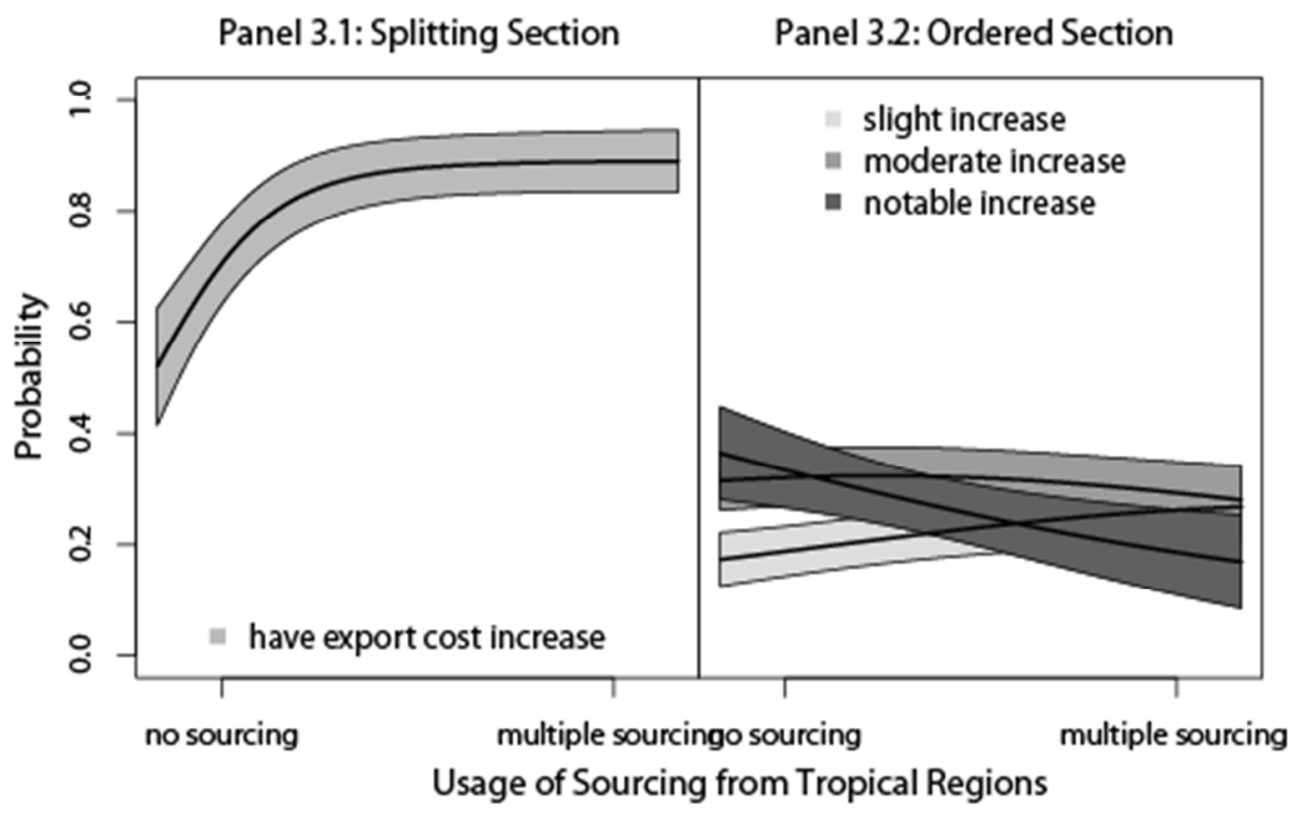


Fig.4 Relation between Sourcing from Local China and Export Cost Increase

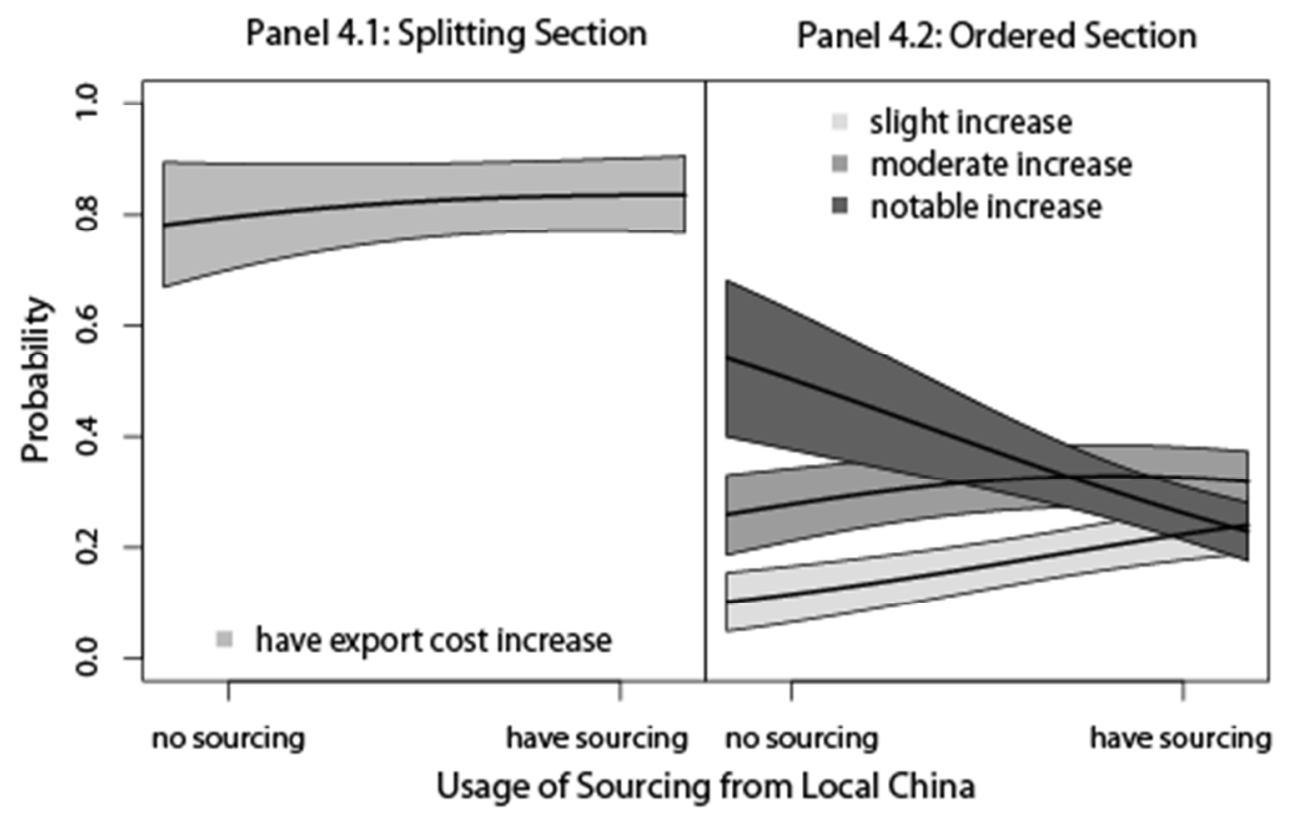


Fig.5 Export Cost Increase by Size

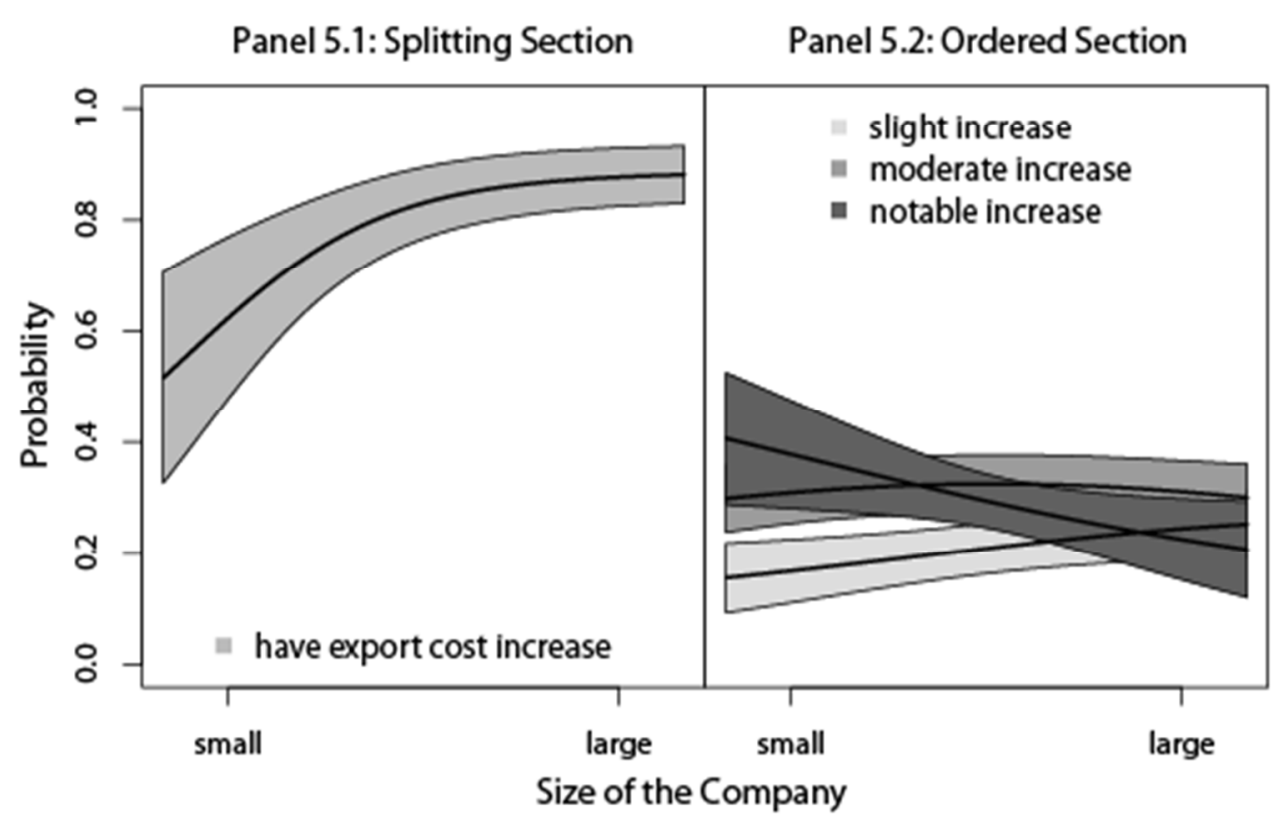

https://mc06.manuscriptcentral.com/cjfr-pubs 